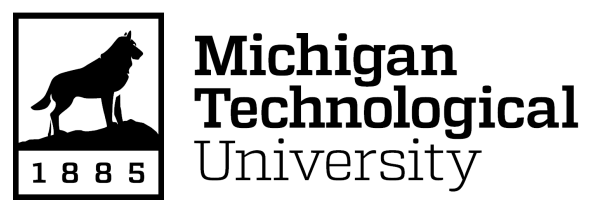

Michigan Technological University Digital Commons @ Michigan Tech

Michigan Tech Publications

$11-15-2020$

\title{
Using TanDEM-X to measure pyroclastic flow source location, thickness and volume: Application to the 3rd June 2018 eruption of Fuego volcano, Guatemala
}

\author{
F. Albino \\ University of Bristol \\ J. Biggs \\ University of Bristol \\ R. Escobar-Wolf \\ A. Naismith \\ University of Bristol \\ M. Watson \\ University of Bristol
}

Michigan Technological University, rpescoba@mtu.edu

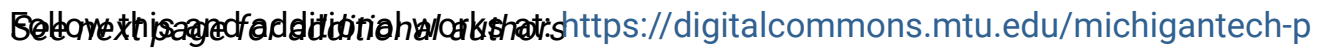 \\ Part of the Geological Engineering Commons, and the Mining Engineering Commons}

\section{Recommended Citation}

Albino, F., Biggs, J., Escobar-Wolf, R., Naismith, A., Watson, M., Phillips, J., \& Chigna Marroquin, G. (2020). Using TanDEM-X to measure pyroclastic flow source location, thickness and volume: Application to the 3rd June 2018 eruption of Fuego volcano, Guatemala. Journal of Volcanology and Geothermal Research, 406. http://doi.org/10.1016/j.jvolgeores.2020.107063

Retrieved from: https://digitalcommons.mtu.edu/michigantech-p/14300

Follow this and additional works at: https://digitalcommons.mtu.edu/michigantech-p

Part of the Geological Engineering Commons, and the Mining Engineering Commons 


\section{Authors}

F. Albino, J. Biggs, R. Escobar-Wolf, A. Naismith, M. Watson, J. C. Phillips, and G. A. Chigna Marroquin 


\title{
Using TanDEM-X to measure pyroclastic flow source location, thickness and volume: Application to the 3rd June 2018 eruption of Fuego volcano, Guatemala
}

\author{
F. Albino a,* ${ }^{\text {a. }}$ Biggs $^{\text {a }}$, R. Escobar-Wolf ${ }^{b}$, A. Naismith ${ }^{\text {a }}$, M. Watson ${ }^{\text {a }}$, J.C. Phillips ${ }^{\text {a }}$, G.A. Chigna Marroquin ${ }^{\mathrm{c}}$ \\ a COMET, School of Earth Sciences, University of Bristol, Wills Memorial Building, Queens Road, Bristol BS8 1RJ, UK

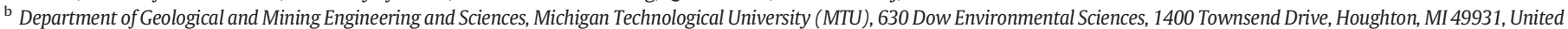 \\ States of America \\ c Instituto Nacional de Sismología, Vulcanología, Meteorología e Hidrología (INSIVUMEH), Guatemala City, Guatemala
}

\section{A R T I C L E I N F O}

\section{Article history:}

Received 30 April 2020

Received in revised form 9 September 2020

Accepted 10 September 2020

Available online 18 September 2020

\section{Keywords:}

TanDEM-X interferometry

Topographic changes

PDC volume

Fuego volcano

\begin{abstract}
A B S T R A C T
The estimation of the volume of volcanic flows during an ongoing eruption is challenging but this information is crucial for improving risk assessment and for forecasting future events. Although previous studies have shown the ability of TanDEM-X satellite data to derive the thickness and the volume of lava flow fields during effusive eruptions, the method has not been explored yet for pyroclastic flows. Using bi-static interferometry, we produce TanDEM-X DEM on Fuego volcano (Guatemala) to measure the significant topographic changes caused by the 3rd June 2018 eruption, which destroyed the town of San Miguel Los Lotes. We estimate the volume of the Pyroclastic Density Currents (PDCs) to be $15.1 \pm 4.2 \times 10^{6} \mathrm{~m}^{3}$. The deposits are likely to be the source of lahars during future rainy seasons. We identify the main channel of deposition (positive elevation changes) and the source region of pyroclastic material, areas of significant substrate erosion, and vegetation destruction (negative elevation changes). Our results show that the June 3rd 2018 pyroclastic flow was predominantly composed of material which had gravitationally collapsed from a location close to the vent. The eroded material increased the volume of the flow (bulking) and likely caused the run-out distance of the 2018 PDC to be larger than previous eruptions (1999-2017). This study highlights the potential of remote sensing techniques for actively monitoring topography changes in inaccessible locations and to rapidly derive deposit volumes.
\end{abstract}

(C) 2020 The Authors. Published by Elsevier B.V. This is an open access article under the CC BY license (http://creativecommons.org/licenses/by/4.0/).

\section{Introduction}

The mapping of volcanic flows (e.g. lava flows, pyroclastic density currents (PDC), lahars) during and after an eruption is essential for forecasting future volcanic behaviour and for refining existing hazard maps, both of which contribute to reducing exposure to risk. Scientifically, the post-eruptive analysis of volcanic flows is used to infer locations of material sources, understand the fundamental processes of flow emplacement and deposition, to provide key observational constraints for models of flow processes, and for benchmarking empirical models (Kelfoun and Druitt, 2005; Cordonnier et al., 2016; Ogburn and Calder, 2017). Accurate topographic data and a good estimate of the flow volume are important as these are key parameters in numerical simulation for forecasting the path and run-out distance of future events (Capra et al., 2011; Charbonnier et al., 2013; Richter et al., 2016).

\footnotetext{
* Corresponding author.

E-mail address: fa17101@bristol.ac.uk (F. Albino).
}

PDC and lahars can be strongly erosive (e.g. Pierson et al., 1990; Calder et al., 2000), so information about eroded volumes and rates is important for formulating and testing numerical models of their dynamics. A critical need is to quantify spatial variations in erosion and deposition over the length of the flow, and to be able to relate this to local flow and topographic conditions. To date, estimates of eroded substrate volume have been limited to detailed measurements at outcrop scale (e.g. Bernard et al., 2014; Kataoka et al., 2018), which is highly informative at a specific location, but impractical to make estimates over the scale of the whole flow. Satellite-imaging of flow deposits has the potential to characterise substrate erosion over significant areas.

During a volcanic crisis, fieldwork is typically limited by accessibility and safety, so remote sensing has become a common method for characterising volcanic activity (Wright et al., 2002; Watson et al., 2004; Joyce et al., 2009; Pyle et al., 2013), including mapping fresh deposits (Kervyn et al., 2007; Smets et al., 2010; Ganci et al., 2018; Pallister et al., 2019). Flow outlines can be mapped using a range of satellites and airborne imagery, but estimating height changes is more challenging. Different methods have been used to produce Digital 
Elevation Model (DEM): 1) Airborne or terrestrial laser altimeters (Glennie et al., 2013; Telling et al., 2017), 2) Optical stereo satellite imagery (Toutin and Cheng, 2001), and 3) Radar Interferometry (InSAR) (Toutin and Gray, 2000; Crosetto, 2002).

High-resolution DEMs (1-25 m) derived from altimeter systems can provide information about the thickness and the morphology of pyroclastic flows after their emplacement (Hofton et al., 2006; Jessop et al., 2012). However, because of its cost and the difficulties of implementation, this approach is not suitable for fast-response to ongoing volcanic events. SPOT stereo images have also been used to build post-eruptive DEMs to derive flow volumes on active stratovolcanoes such as Sinabung and Colima (Yulianto and Sofan, 2016; Dávila et al., 2019); however, the technique only works in daytime and clear sky conditions (e.g. no cloud or no ash plume), which is rare during an eruptive event. Although satellite InSAR is most often used to measure small (centimetre to meter scale) surface deformation, it can also be used to produce DEMs or maps of large-scale (meters to 10s of meters) topographic changes, and is functional both day and night and in all weather conditions. For this reason, InSAR has been widely applied for studying recent lava flow fields in both repeat-pass (Lu et al., 2003; Rowland et al., 2003; Ebmeier et al., 2012) and bistatic/single-pass modes (Poland, 2014; Albino et al., 2015; Kubanek et al., 2015; Richter et al., 2016; Arnold et al., 2017; Dirscherl and Rossi, 2018; Lundgren et al., 2019).

Here, we produce pre- and post-eruptive DEMs using bistatic data from the TanDEM-X mission and quantify the source location, thickness and volume of the Pyroclastic Density Currents (PDCs) generated by the 3 June 2018 eruption of Fuego volcano, Guatemala. In order to reduce the errors associated with previous approaches, we use pre- and posteruptive DEMs derived from the same sensor and processing scheme. We assess the quality of the measurements using i) theoretical relationships based on the acquisition geometry (incidence angle vs. local slope) and surface characteristics (coherence values), and ii) empirical estimates based on the comparison of two pre-eruptive DEMs. We analyse the distribution of positive and negative topographic changes associated with the 2018 PDCs, and we discuss the implications for estimates of deposit volumes and source mechanisms.

\section{Background}

\subsection{Volcán de Fuego, Guatemala}

Fuego is a high-elevation stratovolcano (above $3700 \mathrm{~m}$ ) located within the 145-km long WNW-trending central Guatemalan volcanic chain (Martin and Rose, 1981) (Fig. 1a - inset). It is considered one of the most active volcanoes of the Americas, with over 50 major eruptions (i.e. with Volcanic Explosivity Index VEI $\geq 2$ ) reported since the beginning of the Spanish colonial era in 1524 (Global Volcanism Program, 2013). The eruptive records show periods of low-level continuous Strombolian activity (from months to years) (Waite et al., 2013) interspersed with short-lived sub-Plinian events (from hours to days) (Rose et al., 2008).

One of the largest historically-recorded eruptive events (VEI 4) occurred during October 1974 producing ash fall and pyroclastic flows, which triggered the evacuation of local population and damaged agricultural production (Rose et al., 1978). The Dense Rock Equivalent (DRE) volume erupted was estimated at about $0.1 \mathrm{~km}^{3}$ (Rose et al., 2008). After this period of activity (1974-1979), Fuego had brief Strombolian activity (VEI 1-2) in 1987 and 1999 (Global Volcanism Program, 2013). Since 1999, activity at Fuego has been dominated by persistent Strombolian activity with frequent paroxysmal eruptions producing lava flows and more rarely pyroclastic flows which travelled no more than $6 \mathrm{~km}$ from the summit (Ferres and Escobar Wolf, 2018) (Fig. 1a)

This eruptive cycle changed on 3 June 2018 when a violent explosion occurred at 12:00 (UTC) at the summit causing an ash plume rising up a) Pyroclastic Density Currents (PDC) 1999-2018

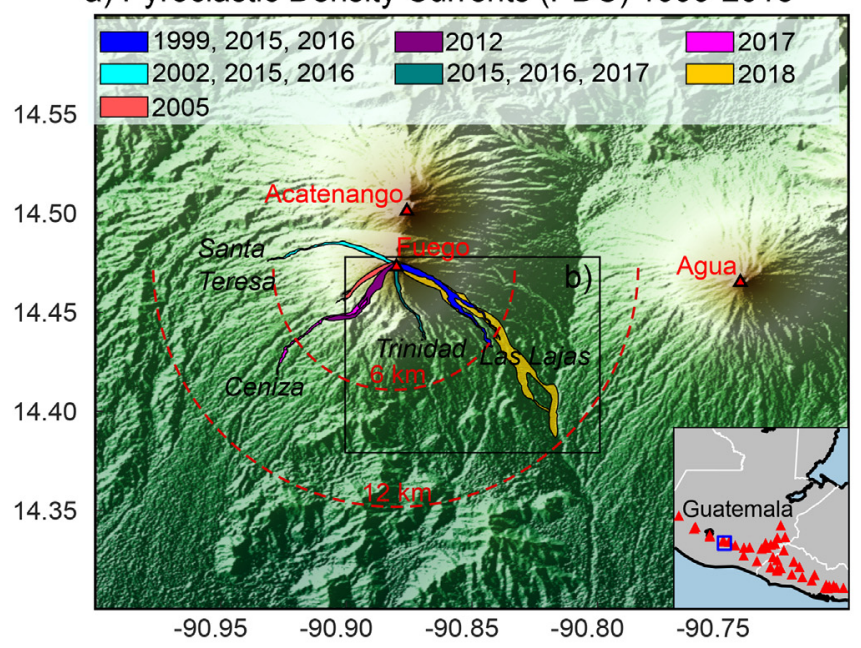

b) Facies of the 2018 PDC

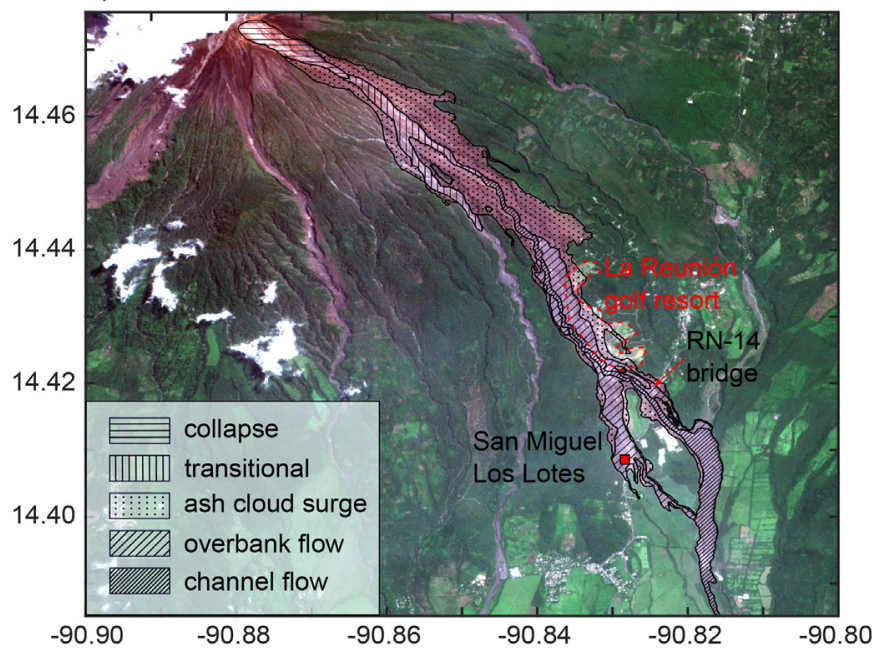

Fig. 1. a) Topographic map based on 90-m resolution SRTM DEM showing the surrounding of Fuego volcano and the path of Pyroclastic Density Currents (PDC) for the period 1999-2018. Dashed red lines indicate run-out distances of 6 and $12 \mathrm{~km}$. The name of the different barrancas are indicated in black. Right bottom inset shows the location of Fuego along the Central America volcanic arc. b) Detailed mapping of the different facies of the 2018 PDC based on a Sentinel-2 image acquired few days after the eruption on 29th June 2018. (For interpretation of the references to colour in this figure legend, the reader is referred to the web version of this article.)

to $15 \mathrm{~km}$ above sea level (reported by the Washington Volcanic Ash Advisory Center, VAAC) and a series of destructive PDCs travelling up to $12 \mathrm{~km}$ from the summit down to Barranca Las Lajas (Fig. 1b). Based on the retrieval of plume height and an eruption column model, Pardini et al. (2019) estimated the Dense Rock Equivalent (DRE) volume to be $0.04 \pm 0.1 \mathrm{~km}^{3}$. The climax of the paroxysm was reached only $5-6 \mathrm{~h}$ after the onset and lasted for $2.5 \mathrm{~h}$ between 17:30 and 20:00 UTC. The local authorities evacuated about 12,000 people, but the rapid-onset eruption still caused hundreds of fatalities (Naismith et al., 2019), especially in the town of San Miguel Los Lotes. As a result, this volcanic event became the third deadliest eruption in the 21st century (at the time of writing). In addition, PDCs destroyed facilities at a golf resort and critical infrastructure, which affected evacuation lifelines including a bridge located on the road RN-14 (Fig. 1b).

\subsection{Satellite measurements of flow volumes}

Repeat-pass radar interferometry estimates height change by calculating the phase difference between two radar images separated in 
time; a reference DEM (acquired before the event) is usually used to remove any phase delays due to relief. The resulting interferogram includes phase changes due to topographic change, but also due to ground deformation or atmospheric artefacts. Despite this, a range of SAR sensors have been successfully used to derive thicknesses of fresh lava flows at Okmok (Aleutians), Cerro Azul (Galapagos) and Santiaguito (Guatemala) (Lu et al., 2003; Rowland et al., 2003; Ebmeier et al., 2012).

In 2010, the TanDEM-X radar mission was launched by the German space agency (DLR) with the aim of producing a world-wide DEM at $12 \mathrm{~m}$ resolution using bi-static interferometry (e.g. two acquisitions of the same area at the same time) (Moreira et al., 2004; Zink et al., 2006; Fritz et al., 2011). Bi-static interferometry is more suitable than repeat-pass interferometry for DEM generation as the phase difference of the interferogram excludes any contribution related to ground deformation or atmospheric delays (Supplementary Fig. 1), and therefore the quality of bi-static DEM is expected to be better. TanDEM-X data have been used to accurately derive the total volume of lava flows at a number of different volcanoes including Kilauea (Hawaii), Nyamulagira (D.R of Congo), Tobalchik (Kamchatka), Fogo (Cape Verde) and Reventador (Ecuador) (Poland, 2014; Albino et al., 2015; Kubanek et al., 2015; Richter et al., 2016; Arnold et al., 2017).

Although TanDEM-X has been widely used for quantifying lava flow volumes during effusive activity, the application to explosive events involving pyroclastic flows is limited. The reason is mainly that the thicknesses of such flows are usually smaller and potentially below the detection threshold obtained using TanDEM-X DEM. Arnold et al. (2016) used a range of satellites and ground-based DEMs to quantify cumulative pyroclastic flow volumes at Soufrière Hills (Montserrat) from 1995 to 2010. In this example, errors on volumes remain large (up to $70 \%$ ) and were mainly caused by the temporal decorrelation of ALOS repeat-pass data, the loss of information in areas of steep topography (effect of layover and shadow), and also the fact that DEMs were generated from different radar wavelengths and may correspond to different topographic surfaces (e.g. L-band has a larger penetration depth in vegetation than X-band).

Although several open-access DEMs of Fuego are available before the June 2018 eruption (e.g. SRTM and ASTER), they all have relatively low spatial resolution ( $\geq 30 \mathrm{~m}$ ) and are not suitable for characterising the narrow valleys $(10 \mathrm{~m}$ ) where the pyroclastic flows were emplaced. For these reasons, we choose to use TanDEM-X bi-static dataset to produce both pre- and post-eruptive DEMs at a spatial resolution of $10 \mathrm{~m}$.

\section{Data and methods}

\subsection{Sentinel-2 optical imagery}

Pyroclastic Density Currents (PDCs) produce several different facies of deposits: i) channel flow deposits associated with the filling of confined valleys, ii) overbank flow deposits where the flow jumped out of the channels and inundated the inter-fluvial terrain and iii) ash-cloud surge thin deposits (few $\mathrm{cm}$ ), which are typically associated with the burning of surrounding vegetation (Schwarzkopf et al., 2005; Charbonnier et al., 2013). First, we use post-eruptive Sentinel-2 optical imagery acquired on 29th June 2018 to identify and map the different facies of the 2018 flow deposits at Fuego (Fig. 1b). Based on the satellite imagery (e.g. colour and texture) and some a priori field knowledge, we distinguish 5 different facies.

The collapse facies (1) is located near the summit and is the source of most of the PDC material. The transitional facies (2) is located on steep slopes and corresponds to the transition between erosion and deposition processes. The ash cloud surge facies (3) is located in the proximal section and corresponds to thin deposition and destruction of vegetation. The overbank flow facies (4) is located near the main channel and corresponds to the escape of the flow onto the interfluvial terrain. The ash cloud surge facies was easily distinguished from the overbank facies by its characteristic reddish colour on the Sentinel-2 image. The channel flow facies (5) is located in the medial to distal section and corresponds to valley-filling deposits.

\subsection{TanDEM-X digital elevation models}

Six TanDEM-X acquisitions were available at Fuego volcano for the period 2015-2018: two ascending ones before the 2018 eruption (18 October and 29 October 2015) and four acquisitions after the eruption with two ascending (6 August and 8 September 2018) and two descending (19 September and 22 October 2018). We used SARScape $C$ to process the SAR images, which consists of different steps: coregistration of the Single Look Complex (SLC) images, flattening, phase unwrapping and geocoding. A detailed description of TanDEM-X processing with SARscape $@$ can be found in Sahraoui et al. (2006). We apply a multilooking of 4 to produce a Digital Elevation Model with a spatial resolution of $10 \mathrm{~m}$. The SRTM ( 1 " second DEM) is used as the reference topography during the flattening step to remove the highfrequency phase gradient due to relief. This facilitates the phase unwrapping as only residual fringes associated with topographic changes (occurring after the year 2000) will be present in the flattened interferograms. The phase contribution of the SRTM topography is added back to the residual interferogram after unwrapping to obtain the final TanDEM-X DEM.

The ascending dataset is most useful for the estimation of the DEM difference because we have pre-eruptive and post-eruptive DEMs for comparison. By looking at the DEM differences, we identified phase ramps in the range direction $(0.03-0.45 \mathrm{~m} / \mathrm{km})$, which are likely to be caused by orbit inaccuracies or misalignment between DEMs (Poland, 2014; Millan et al., 2015; Neelmeijer et al., 2017). In the absence of accurate ground control points, we correct the ramps by systematically removing a plane from each DEM difference calculated (see Supplementary Fig. 2). As we are primarily interested in the difference between DEMs rather than absolute elevation the lack of ground control points does not have a significant impact on our analysis.

\subsection{Optimal spatial resolution}

Our ability to detect small topographic changes from a DEM depends on the spatial resolution and the precision of the elevation measurements. High-resolution data enables us to better detect changes occurring over small areas (e.g. inside the crater of a volcano or inside incised valleys). The optimal ground resolution $\delta_{g r}$ of TanDEM-X DEM is a function of the viewing geometry (Hanssen, 2001):

$\delta_{g r}=\frac{\delta_{s r}}{\sin \theta}$

where $\delta_{s r}$ is the pixel spacing slant range and $\theta$ is the local incidence angle (Supplementary Fig. 1a). Therefore, the optimal resolution varies for each pixel and will depend on the terrain slopes: high-resolution (small values of $\delta_{s r}$ ) will be obtained for slopes oriented away from the satellite, and inversely coarse resolution will be retrieved for slopes oriented towards the LOS.

In the case of Fuego, the optimal ground resolution for ascending DEMs ranges from 5 to $10 \mathrm{~m}$ on the eastern flank whereas it exceeds $20 \mathrm{~m}$ on the western flank (Supplementary Fig. 3a). Results will be reversed for descending data with higher resolution on the western flank. For the 2018 eruption, as pyroclastic flow were emplaced on the eastern flank, we expect better results using ascending track DEMs.

\subsection{Vertical accuracy and precision}

The vertical accuracy of a DEM can be evaluated by comparing its elevation with more accurate ground data such as GNSS measurements 
(Albino et al., 2015; Balzter et al., 2016; Wessel et al., 2018). However, we do not have GPS measurements for the studied area and here we only evaluate precision rather than accuracy. This is not a limitation for our study as we are not interested in the absolute value of the elevation but only the elevation difference.
Because TanDEM-X DEMs are processed using the same reference DEM, we expect any vertical bias to be consistent across the entire dataset. In theory, the vertical precision of TanDEM-X DEM is correlated with the SAR geometry and the coherence values, which correspond to the variations in scattering characteristics of all ground targets a) pre-eruptive DEM difference

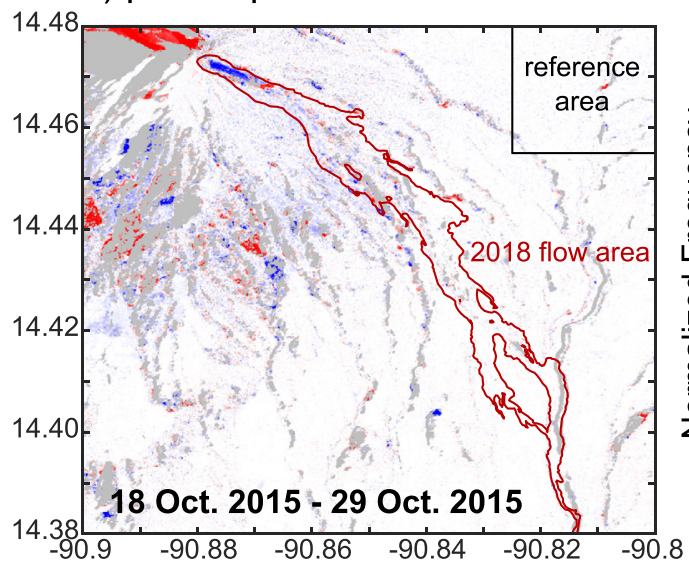

b) co-eruptive DEM difference

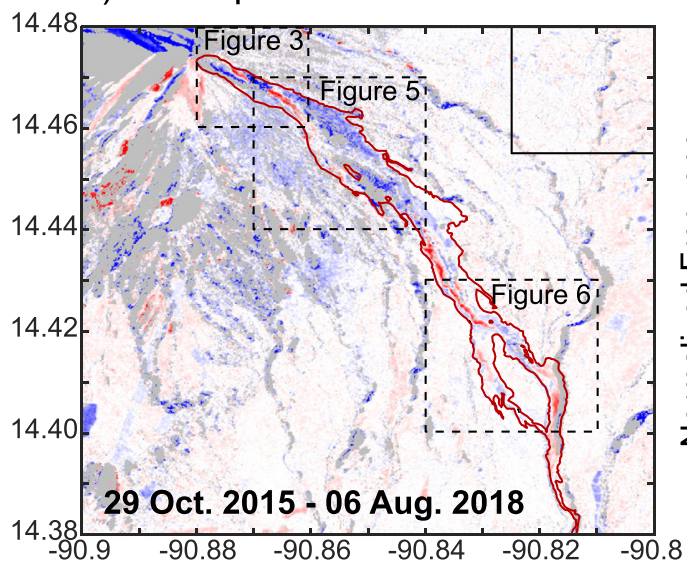

c) post-eruptive DEM difference

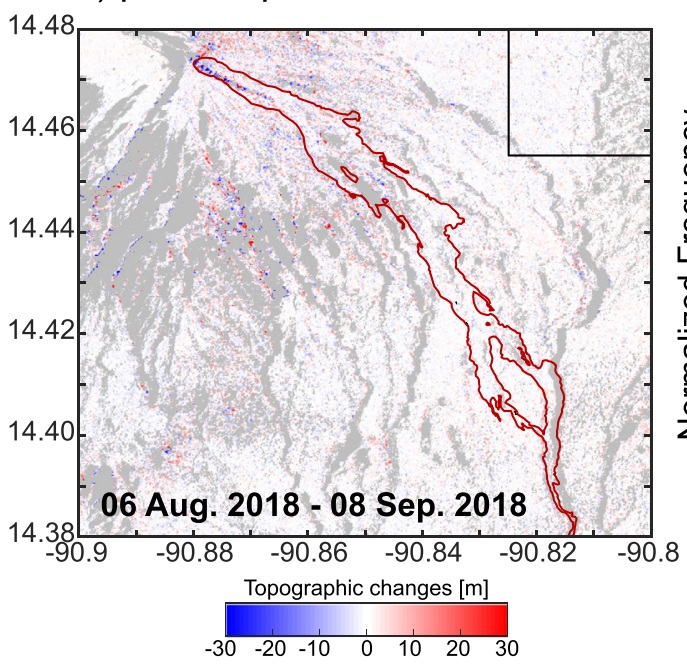

d) pre-eruptive histogram

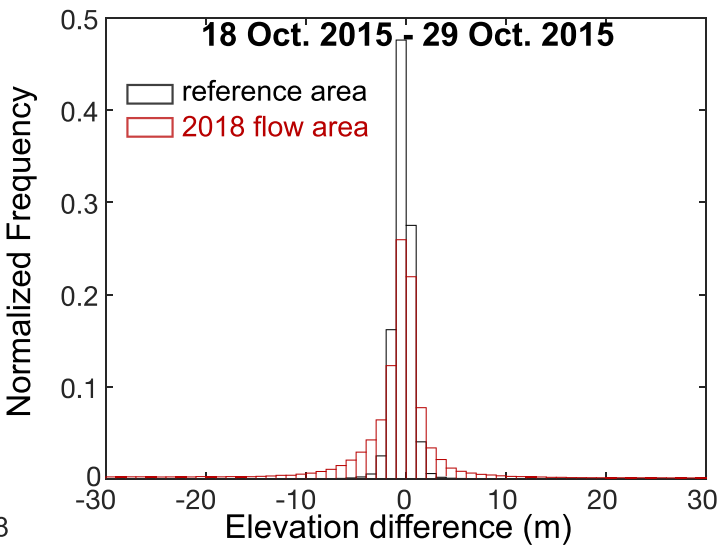

e) co-eruptive histogram

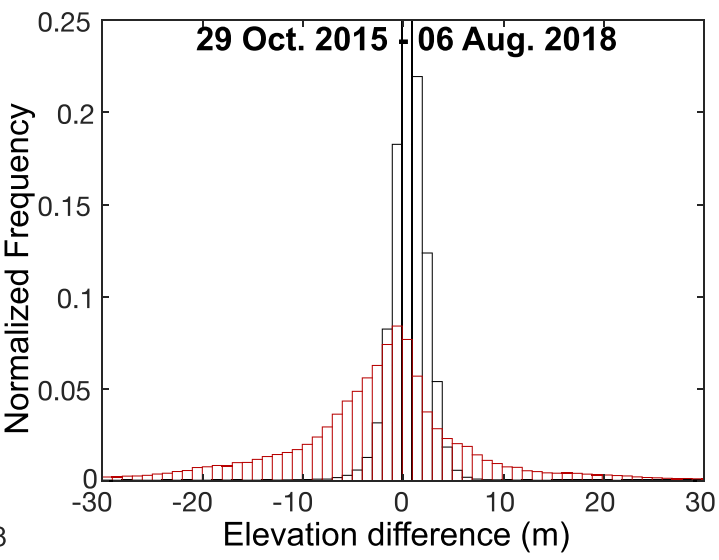

f) post-eruptive histogram

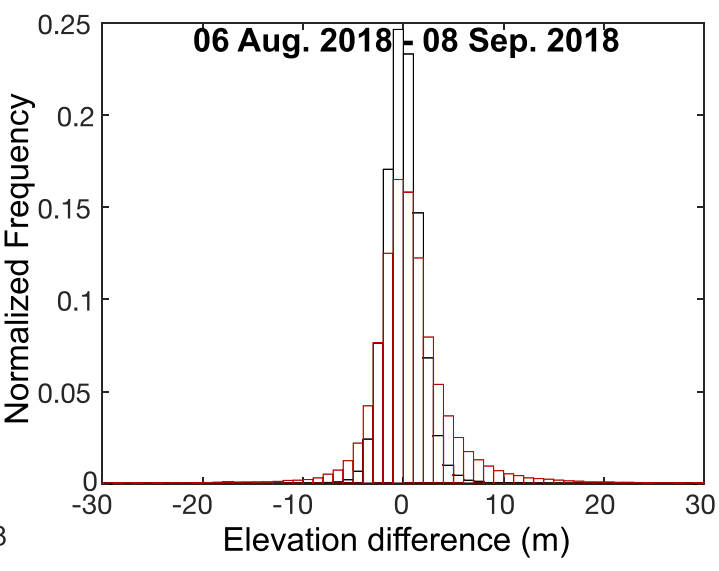

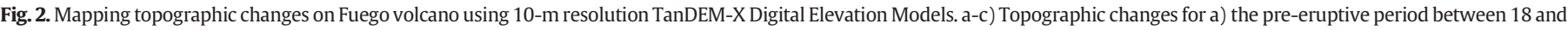

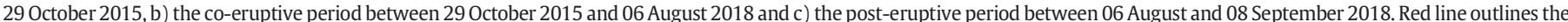

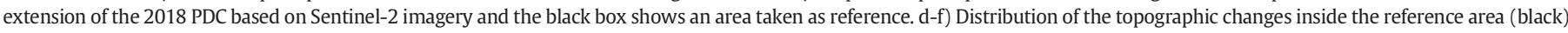

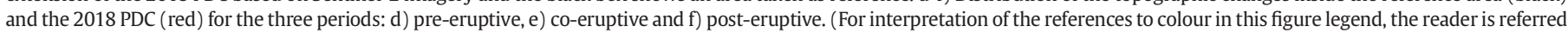
to the web version of this article.) 
contained in a pixel and range from 0 (total decorrelation) to 1 (phase correlation is preserved). The DEM precision $\sigma_{z}$ can be approximated through the following relationship (Krieger et al., 2007):

$\sigma_{z}=\frac{H_{a}}{2 \pi} \sigma_{\phi}$

where $H_{a}$ is the height of ambiguity (e.g. height change corresponding to a $2 \pi$ phase cycle) and $\sigma_{\phi}$ the standard deviation of the interferometric phase errors. For the bi-static case, the height of ambiguity is expressed as $H_{a}=\frac{\lambda R \sin \theta}{\pi B}$, with $\lambda$ the radar wavelength ( $3.1 \mathrm{~cm}$ for TanDEM-X), $R$ the slant range distance, $\theta$ the local incidence angle and $B$ the perpendicular baseline (see Supplementary Fig. 1). The standard deviation of the phase is approximated by the Cramer-Rao bound: $\sigma_{\phi}=\sqrt{\frac{1-\gamma^{2}}{2 N \gamma^{2}}}$ with $\gamma$ the coherence value and $N$ the number of looks (here $N=4$ ) (Rodriguez and Martin, 1992; Seymour and Cumming, 1994).

The vertical precision of the DEMs is best (low value of $\sigma_{z}$ ) for areas of high coherence. For example, Albino et al. (2015) showed that the vertical precision of TanDEM-X DEM on Nyamulagira volcano is 10 times better for old lava flows $(0.4 \mathrm{~m})$ than for vegetated regions $(5.5 \mathrm{~m})$. We evaluate the vertical precision of the TanDEM-X DEMs at Fuego (Supplementary Fig. 3b). Although the lower slopes of Fuego volcano are covered by dense tropical vegetation, DEM precision remains under $5 \mathrm{~m}$ for most of the studied area. The lowest precision values $(>15 \mathrm{~m}$ ) are located on high slopes on the SW flank and in deep valleys, where SAR shadowing occurs. We use the above quality assessment to mask DEM elevation in areas where either the precision or the optimal resolution are greater than $15 \mathrm{~m}$.

\section{Elevation changes}

\subsection{Detection of the elevation changes and evaluation of the uncertainties}

Using the four ascending TanDEM-X DEMs, we consider the height differences for three different time periods: pre-eruptive (18 and 29 October 2015), co-eruptive (29 October 2015 and 06 August 2018) and post-eruptive (06 August and 08 September 2018) (Fig. 2a-c). For each period, we look at the distribution of the elevation changes over two regions with equal area: (i) a square reference area located far from the valleys and (ii) the 2018 flow area (Fig. 2a). Inside the 2018 flow area, only $12 \%$ of the pixels are masked due to low resolution $\left(\delta_{g r}>15 \mathrm{~m}\right)$ or poor precision $\left(\sigma_{z}>15 \mathrm{~m}\right)$, which gives confidence that we should be able to detect topographic changes related to volcanic activity.

In the reference area, we do not expect any topographic changes caused by volcanic activity. The Gaussian distribution of the values characterises the uncertainties of the measurements and the ongoing processes of erosion and sedimentation (Fig. $2 \mathrm{~d}-\mathrm{f}$ ). The mean value is dominated by the vertical offset between DEMs and the standard
TanDEM-X DEM differences
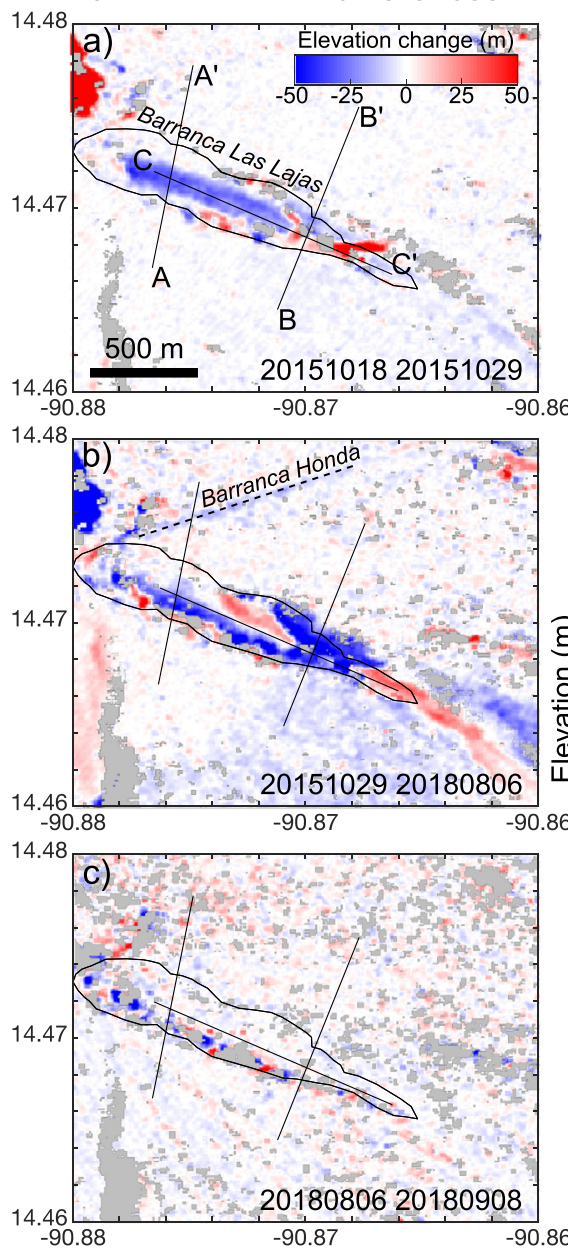

\section{Elevation profiles}
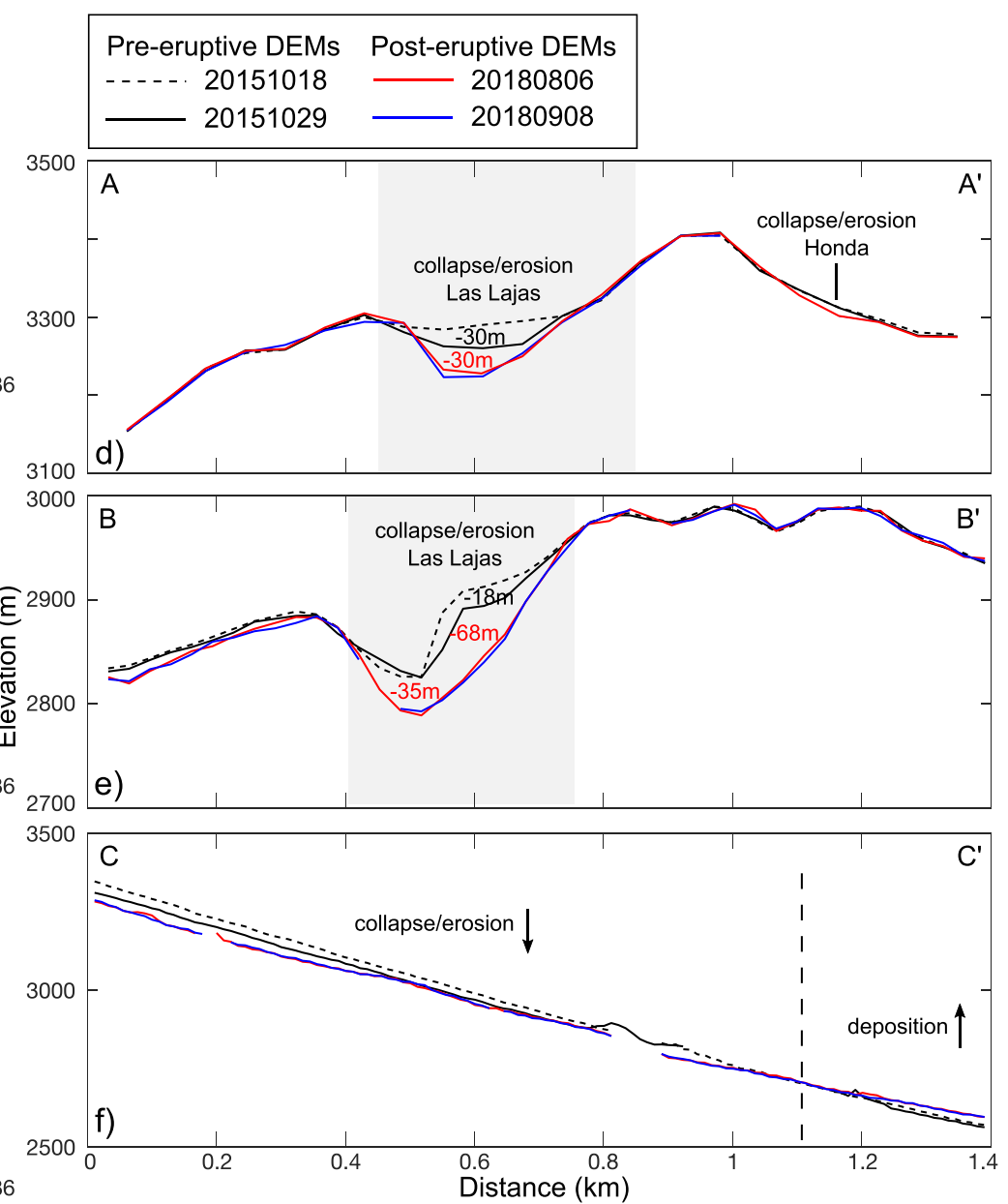

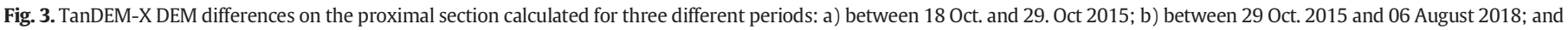

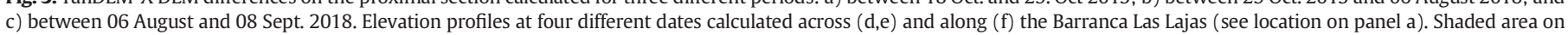
profiles AA' and BB' profiles indicates the lateral extend of the 2018 collapse facies originally mapped from Sentinel-2 imagery (Fig. 1b). 
deviation corresponds to the limit of detection of elevation changes. For the three periods, the mean value remains lower than $1 \mathrm{~m}$, which confirms there are no significant residual vertical offsets between the DEMs and that there is little net erosion or sedimentation. For pre-eruptive, co-eruptive and post-eruptive elevation difference, the standard deviation remains consistent with values of 1.6, 2.1 and $1.6 \mathrm{~m}$. Based on this metric, our method has the potential to detect elevation changes greater than $2 \mathrm{~m}$ on Fuego and its surroundings.

For the pre-eruptive DEM difference, we observe small negative changes of up to $30 \mathrm{~m}$ in the proximal section of Barranca Las Lajas, near the volcano's summit (Fig. 2a). Inside the 2018 flow area, we obtain a negative mean of $-1.1 \mathrm{~m}$ and a standard deviation of $5.9 \mathrm{~m}$, which is higher than for the reference area (Fig. $2 \mathrm{~d}$ ). These changes are likely related to a period of minor volcanic activity that occurred during October 2015 (Naismith et al., 2019). The Instituto Nacional de Sismología, Vulcanología, Meteorología e Hidrología (INSIVUMEH) reported an increase of activity between 21 and 27 October 2015 with a gas-and-ash plume up to $1.2 \mathrm{~km}$, lava fountains and emplacement of lava flows that extended as far as $1.5 \mathrm{~km}$ on Barrancas Teresa, Trinidad and Las Lajas (Global Volcanism Program, 2013). We discuss the origin of these negative topographic changes in the next Section 4.2.

For the co-eruptive period, we observe large elevation changes inside the 2018 flow area as expected (Fig. 2b). The standard deviation inside the flow area reaches $10.8 \mathrm{~m}$, which is almost twice as big as the one obtained for the pre-eruptive period (Fig. 2e). This confirms the presence of significant topographic changes inside Barranca Las Lajas between October 2015 and August 2018. In the detail, we can observe two distinct features: (i) large negative topographic changes (blue) located mostly on the proximal section of the flow and (ii) thin channels of positive topographic changes (red) on the distal section of the flow (Fig. 2b).

For the post-eruptive period, no significant elevation changes are detected inside the 2018 flow area comparing to previous periods (Fig. 2c). As a result, the mean and the standard deviation values found are the lowest with $0.1 \mathrm{~m}$ and $5.1 \mathrm{~m}$, respectively (Fig. 2f). Therefore, the post-eruptive DEM difference will be used later as a reference to assess thickness and volume uncertainties.

\subsection{Topographic changes near the summit}

We observe negative topographic changes in the proximal section of Barranca Las Lajas in both pre-eruptive and co-eruptive pairs (Fig. 3a,b). The signal is located in an area of high resolution and high precision and is not present in the post-eruptive pair (Fig. 3c), which suggests it is true topographic change rather than an artefact.

For the co-eruptive pair, large negative elevation changes occur in the upper $1.5 \mathrm{~km}$ of Barranca Las Lajas, with a maximum amplitude of $68 \mathrm{~m}$ occurring less than $1 \mathrm{~km}$ from the volcano's summit (Fig. 3b,e). Several eruptions occurred during the period between October 2015 and September 2018, which makes interpretation of the topographic changes in the proximal section of the flow challenging. However, we attribute the majority of this elevation change to collapse during the June 2018 eruption. This is confirmed by a series of field photographs taken from La Reunión golf resort, which shows the removal of volcanic materials in the Barranca Las Lajas between March 2017 and March 2019 (Fig. 4). In the co-eruptive DEM difference, we also observe small negative topographic changes at Barranca Honda (dashed line in Fig. 3b). This corresponds with a collapse scar already detected using high-resolution optical imagery and attributed to the February 2018 eruption (Aldeghi et al., 2019).

For the pre-eruptive pair, negative elevation changes extend about $1 \mathrm{~km}$ along the Barranca Las Lajas (Fig. 3a) with a maximum amplitude of about $30 \mathrm{~m}$ (Fig. 3d). This collapse is likely associated with volcanic activity on 21-27 October 2015. At that time, the emplacement of lava flows and PDCs in the barrancas could have caused the erosion and/or collapse of volcanic materials previously emplaced at the summit.

Thus, based on the DEM analysis, we show that mass removal of volcanic material ( $30 \mathrm{~m}$ thickness) occurred repetitively in the upper

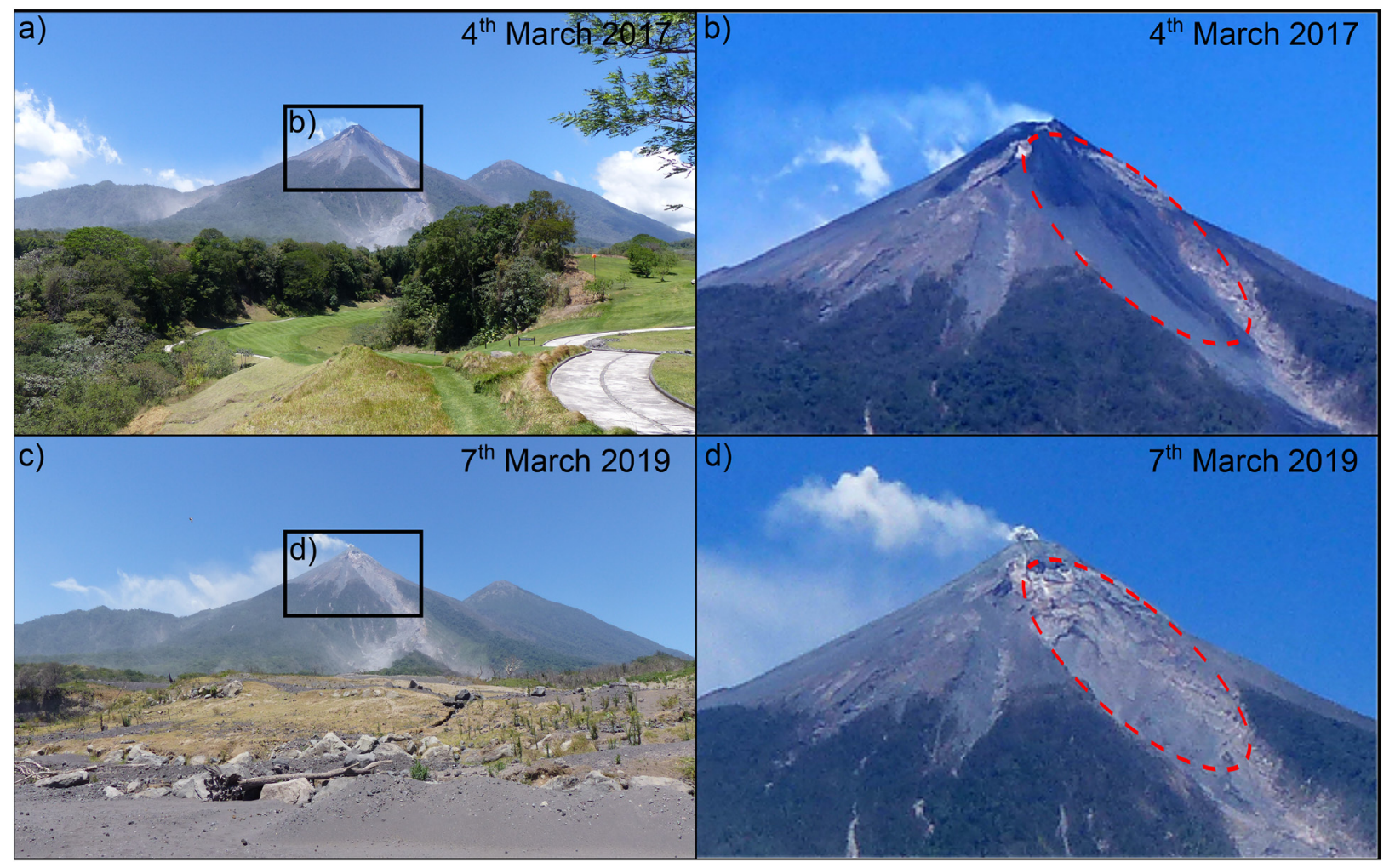

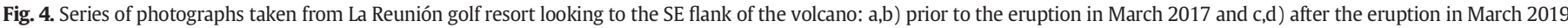

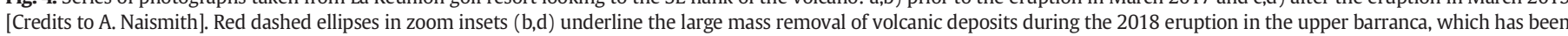
detected by TanDEM-X DEM difference (Fig. 3b). (For interpretation of the references to colour in this figure legend, the reader is referred to the web version of this article.) 
reaches of Fuego's barrancas. During the 2018 eruption, a particularly large collapse occurred in Barranca Las Lajas removing a large volume of pre-existing deposits. Further down-stream, we observe the transition from negative to positive topographic changes, which corresponds to the deposition of material during the 2018 PDCs (Fig. 3b,f).

\subsection{Distribution of the topographic changes over the PDCs}

For the intermediate and distal sections of the 2018 PDCs, no topographic changes are associated with the 2015 October eruption (Fig. 2a), so we will only evaluate the DEM difference occurring between 29 October 2015 and 06 June 2018. By comparing our TanDEM$X$ DEM difference with Sentinel-2 optical images, we evaluate the relationship between depositional facies and topographic changes.

In the intermediate section, the PDC is mainly composed of the transitional and ash cloud surge facies (Fig. 5a,b). The ash cloud surge facies induced large negative topographic changes up to $20 \mathrm{~m}$, which are caused by the removal of the vegetation. Field observations show that leaves have been stripped or burned from the trees whereas trunks remained standing. Before the surge, $\mathrm{X}$-band radar was scattered from the leaves, but after it is scattered from the ground, causing a negative elevation change equivalent to the height of the trees These changes are consistent along the flow as illustrated by the elevation profile shown in Fig. 5d. Although some deposition may be occurring, the thickness of the surge deposit is less than the height of the removed vegetation, so will be obscured. For the transitional facies, we only observe small positive topographic changes in the NW corner (Fig. 5c), where deposits have accumulated in a narrow channel.

In the distal section, slopes are gentle and the accumulation of deposits is expected to be the largest. The 2018 PDC flow is composed of channel and overbank deposits (Fig. 6a,b). The channel facies is associated with positive topographic changes corresponding to the filling of the valley (Fig. 6c). The thickness of PDC deposits reaches up to $25 \mathrm{~m}$ at locations where the flow was channelised and buttressed against topographic highs (Fig. $6 \mathrm{~d}$ - profile AA'). On the western branch of the flow, the PDCs overtopped the western wall of the channel (Fig. $6 \mathrm{~d}$ profile BB') and hit San Miguel Los Lotes burying houses under 5-10 m of deposits. On the eastern branch, the PDCs destroyed the RN14 bridge and further downstream the accumulation of material is significant with thicknesses up to $20 \mathrm{~m}$ (Fig. 6d - profile CC'). We expect that some of this material will likely be a production zone for future lahars. In addition, we observe negative values on the overbanks due to the destruction of the vegetation (Fig. 6c) as already discussed in the intermediate section. The transition between positive values inside the channel due to deposition and negative values on the overbank is very sharp (Fig. 6d).

Although the detection of topographic changes associated with pyroclastic flows are challenging, our study case illustrates that it can a) Pre-eruptive Sentinel-2 image

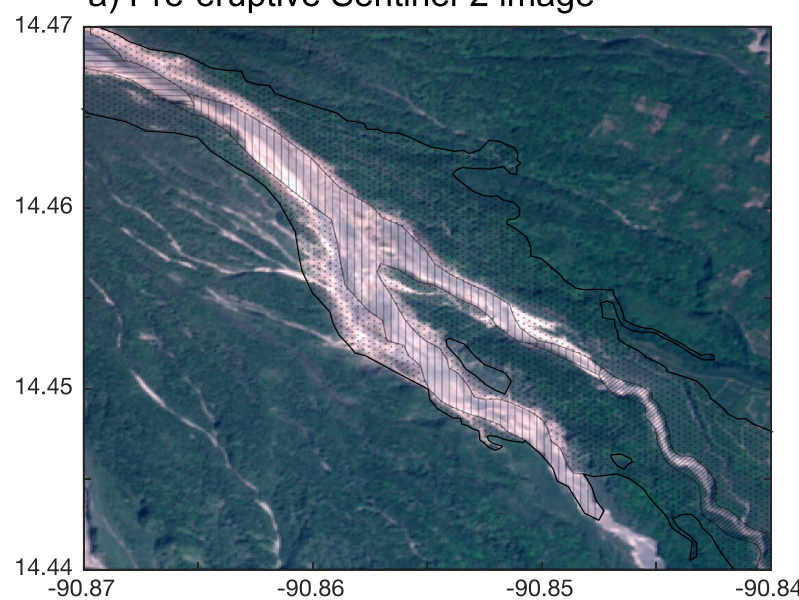

c) TanDEM-X DEM difference

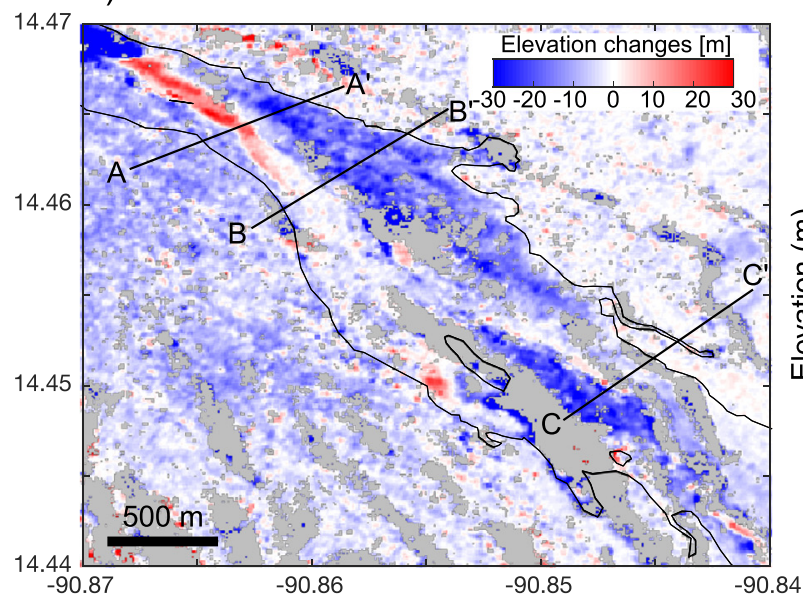

b) Post-eruptive Sentinel-2 image

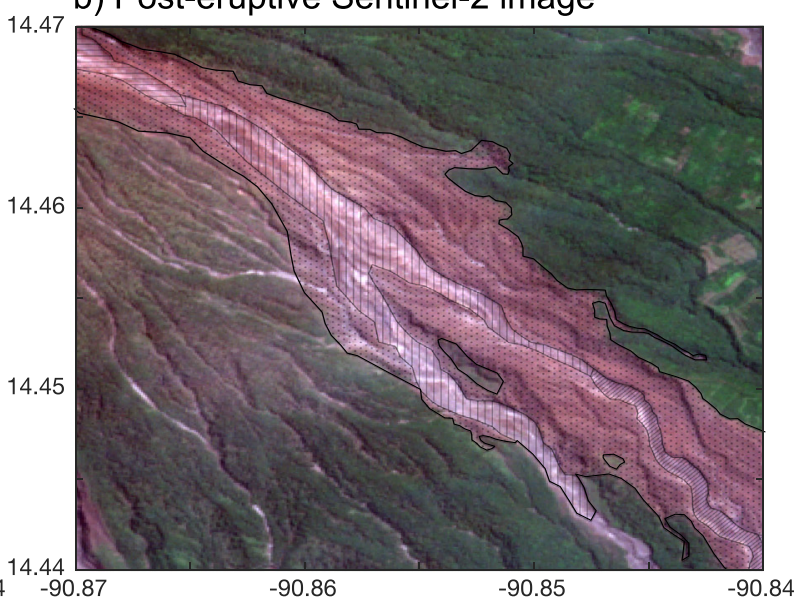

d) Elevation profiles
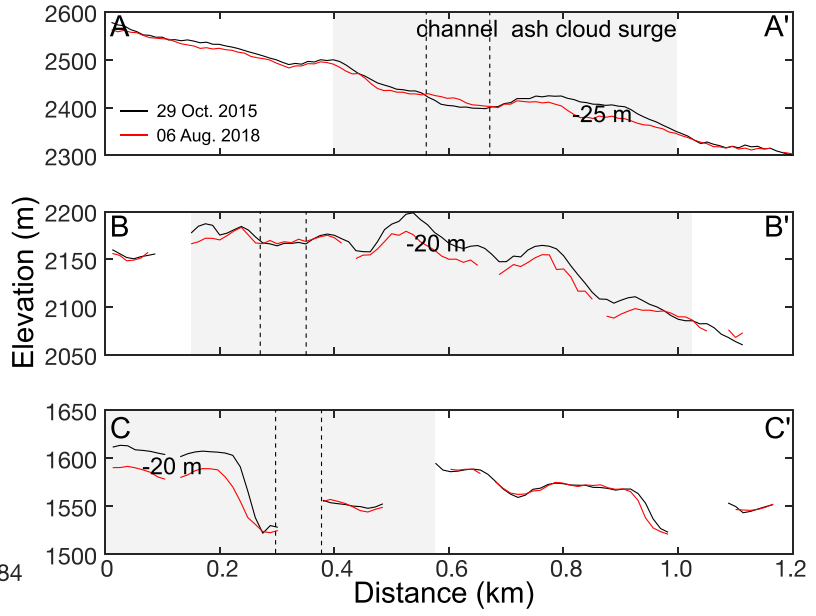

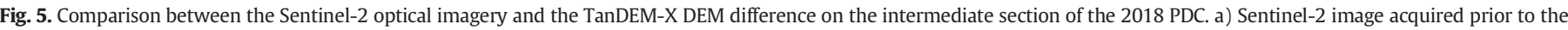

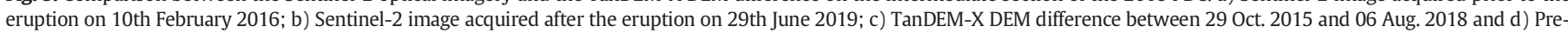
and post-eruptive elevation profiles calculated across the 2018 PDCs. Shaded area indicates the spatial extend of the PDC and the dashed lines show the limit of the channel. 
a) Pre-eruptive Sentinel-2 image

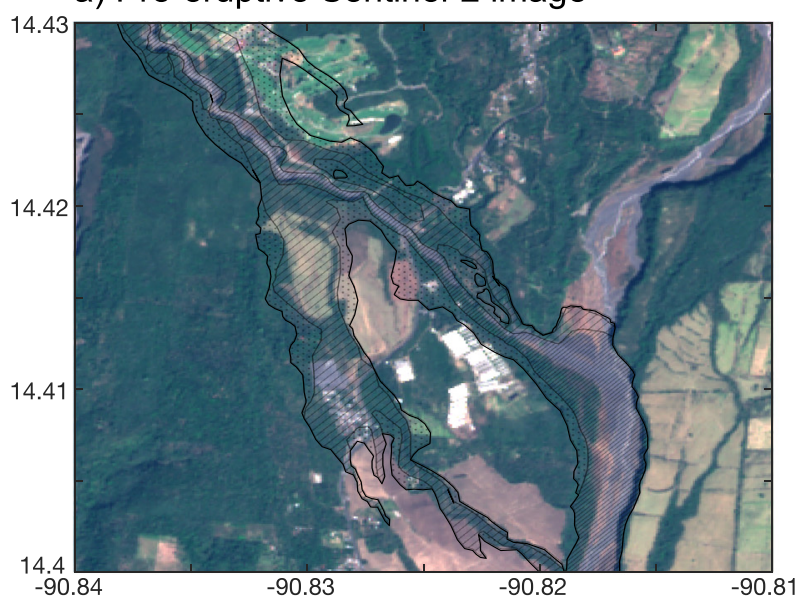

c) TanDEM-X DEM difference

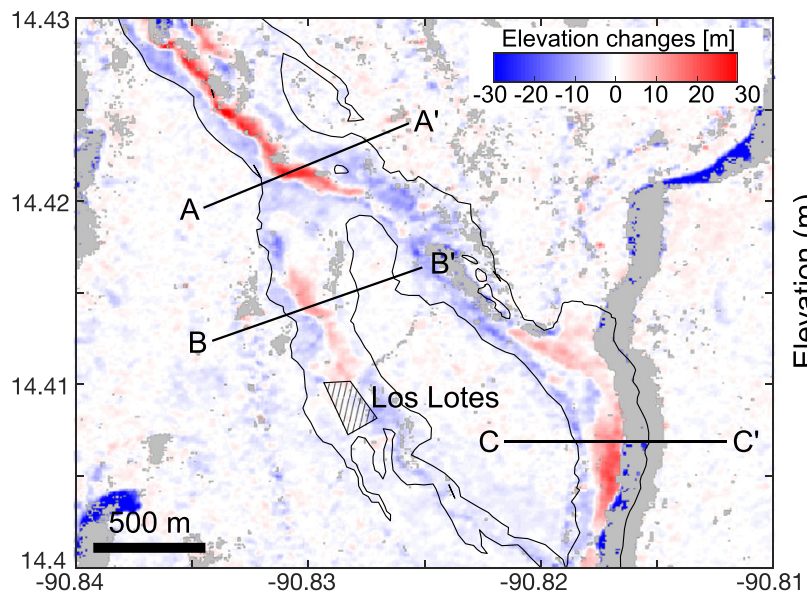

b) Post-eruptive Sentinel-2 image

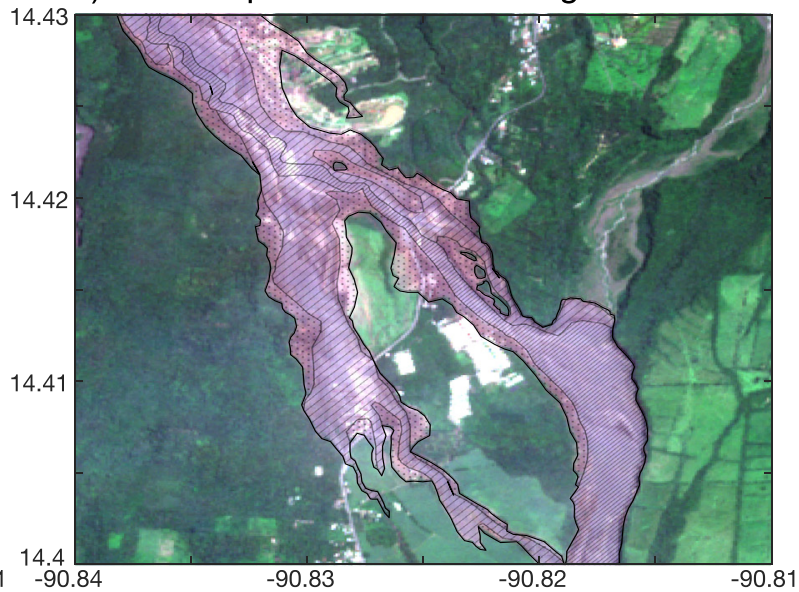

d) Elevation profiles
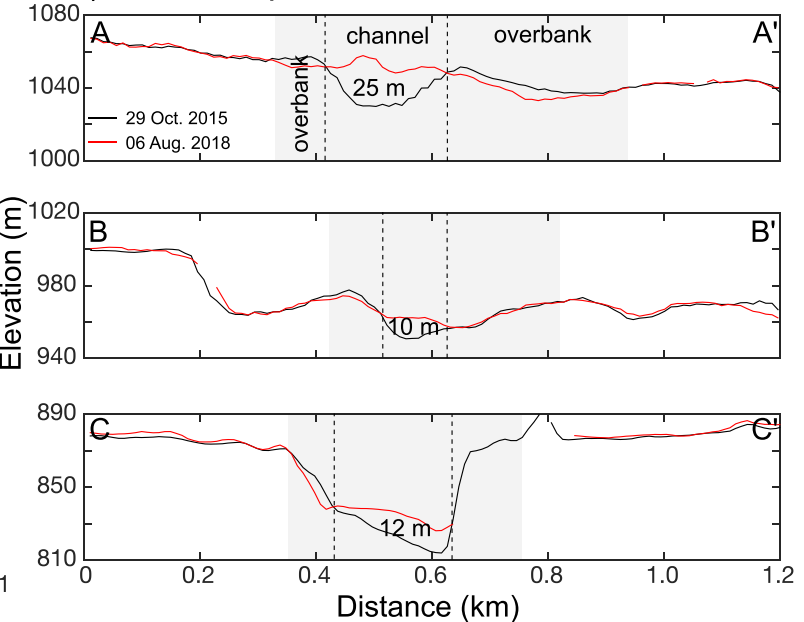

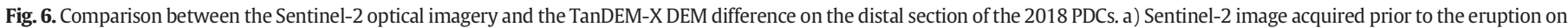

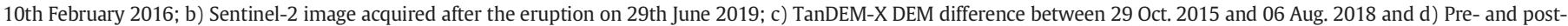
eruptive elevation profiles calculated across the 2018 PDCs. Shaded area indicates the spatial extend of the PDC and the dashed lines show the limit of the channel.

provide valuable information on a range of processes occurring during or after the emplacement of PDCs (e.g collapse, erosion, deposition, and remobilisation).

\section{Volume changes}

\subsection{Total flow volume}

We estimate the total volume changes caused by the 2018 PDCs by the integration of the co-eruptive elevation difference for all pixels located inside the total flow area (Fig. 2b). We discriminate between the positive and the negative values and find volumes of $+15.1 \times 10^{6} \mathrm{~m}^{3}$ and $-38.3 \times 10^{6} \mathrm{~m}^{3}$, respectively (Fig. 7a). Volume uncertainties are estimated by considering a height error of $1.6 \mathrm{~m}$ for each pixel located inside the flow area, which corresponds to the standard deviation obtained for the reference area. We therefore obtain volume uncertainties of $4.2 \times 10^{6} \mathrm{~m}^{3}$ and $7.6 \times 10^{6} \mathrm{~m}^{3}$ for the positive and negative volumes, respectively.

Our estimate of the total deposit volume of $15.1 \pm 4.2 \times 10^{6} \mathrm{~m}^{3} \mathrm{com}-$ pares well with similar volume estimates derived from (1) preliminary investigation after the eruption $\left(20-30 \times 10^{6} \mathrm{~m}^{3}\right.$ ) (Naismith et al., 2019) and (2) high-resolution satellite imagery of Barranca Las Lajas immediately post-event $\left(18.6 \pm 12.4 \times 10^{6} \mathrm{~m}^{3}\right.$ in channel and $5.6 \pm$ $5.0 \times 10^{6} \mathrm{~m}^{3}$ in overbank) (Ferres and Escobar Wolf, 2018). These earlier estimates were based on mapped flow areas multiplied by an average flow thickness based on field observations, which likely overestimates the true volume. In contrast, our volume estimates are based on actual elevation changes, but should be treated as a minimum for several reasons: 1) post-eruptive remobilisation of primary deposits by lahars between the June eruption and the image acquisition in August 2018,2 ) negative signals caused by the destruction of the vegetation which possibly mask small positive changes due to deposition and 3) large DEM uncertainties in some areas due to SAR geometry (e.g. $12 \%$ of the pixels have been masked inside the flow due to poor precision and low resolution).

We notice that the total negative volume is more than twice the positive volume (Fig. 7a), which can be explained by the fact that negative topographic changes are associated with vegetation removal as well as real topographic changes. To quantify the contribution of these two processes, we identify where dense vegetation was present prior to the 2018 eruption using Sentinel-2 optical images. After calculation, vegetation loss corresponds to more than half of the negative topographic changes (Fig. 7a - pale blue), and the volume of erosion $(-17.0 \pm$ $\left.2.8 \times 10^{6} \mathrm{~m}^{3}\right)$ is now in the same order of magnitude as the volume of deposition $\left(15.1 \pm 4.2 \times 10^{6} \mathrm{~m}^{3}\right)$ within error. Based on these results, we demonstrate that increasing the volume of PDCs due to erosion, known as bulking, largely accounts for the total volume of PDCs deposits emplaced during the 2018 Fuego eruption. 


\subsection{Volume change by facies}

We estimate the volume budget for each of the five facies separately to provide information about the emplacement mechanisms of the 2018 PDCs (Fig. 7b). The ash cloud surge facies contributes more than $80 \%$ of the negative topographic changes associated with vegetation loss. Hot materials present in the surge have largely burned and destroyed the vegetation, especially on the eastern side of the flow (Fig. 5a,b).

By comparing the volumes of deposition and erosion, we observe an anti-symmetric behaviour between proximal and distal facies (Fig. 7b). The largest positive volumes are associated with the distal facies (e.g. overbank and channel) whereas the negative volumes are mainly associated with the proximal facies (e.g. collapse and transitional). The ratio between the volumes of deposition and erosion progressively increases with the distance from the volcano summit: collapse (0.3), transitional (0.8), overbank (2.6) and channel (6.9), which would imply a transition mechanism from the upper to the lower slopes. This is confirmed by the trend obtained when plotting the net volume (deposition + erosion) as a function of the mean slope for each facies (Fig. 7c). The transition between erosion and deposition occurs for slopes between 20 and $29^{\circ}$, which is consistent with previous modelling results (Bernard et al., 2014).
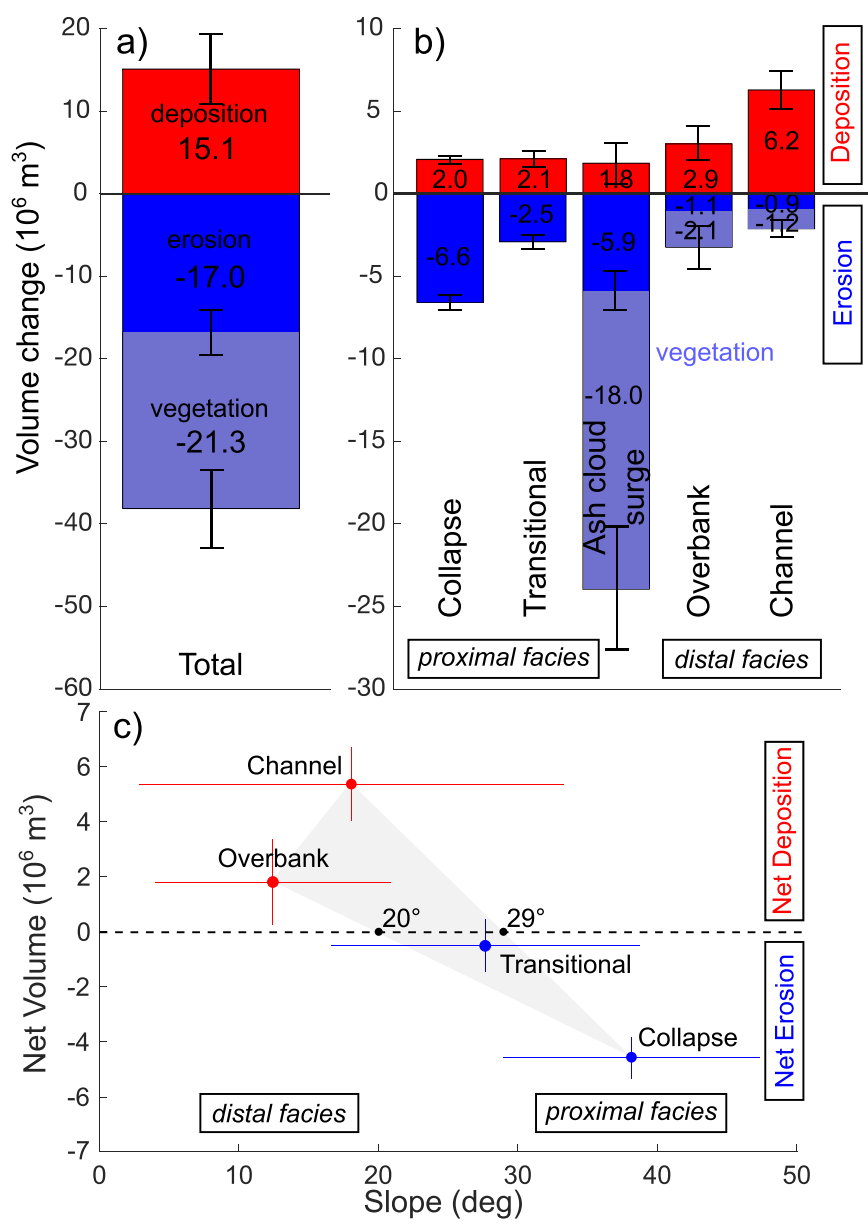

Fig. 7. Volume estimates of the positive (red) and negative (blue) topographic changes with the corresponding uncertainties calculated for a) the total flow area and b) the five different PDCs facies. Dark and pale blue boxes correspond to the processes of erosion and vegetation loss, respectively. c) Net volume (deposition + erosion) as a function of the mean slope for the four facies: channel, overbank, transitional and collapse. The shaded area indicates the transition between proximal and distal facies. (For interpretation of the references to colour in this figure legend, the reader is referred to the web version of this article.)

\section{Discussion}

6.1. Benefit of remote sensing for detecting flow erosion and bulking processes during PDC emplacement

Previous field-based and modelling studies have shown that the bulking (e.g. "the incorporation of material that increases a flow's solid volume fraction" (Iverson, 2012)) results in greater flow mobility, both increasing flow velocity and volume and resulting in greater runout distances (Bernard et al., 2014). The utility of remote sensing techniques in detecting bulking and erosional processes for an entire flow, rather than a few outcrops, is important for improved characterisation of PDC dynamics, allowing detection of local processes occurring at different times and locations within the same flow. Such techniques may inform understanding of rheological controls on pyroclastic flow deposition, as suggested by Kelfoun (2011), and in turn help to identify areas of slope that may be more susceptible to processes of bulking or erosion during PDC descent in future eruptions.

The example of the 3rd June 2018 eruption of Fuego demonstrates that remote sensing datasets can provide relevant post-eruptive information about the emplacement of PDC and their impact on the landscape. Our TanDEM-X survey provides a quantification of mass loss/ accumulation including in the upper slopes, where field observations are difficult or even impossible. This is important because these steep upper slopes are the source location of bulking and erosion and the better quantification of this will improve our understanding of the mechanism of emplacement of PDCs. For the 2018 Fuego eruption, we estimate that a large fraction of the total PDC volume originated from the mass removal of volcanic deposits, which accumulated during previous eruptions at the summit of the Barranca Las Lajas.

\subsection{Benefit of remote sensing for the monitoring of mass accumulation/col-} lapse on stratovolcanoes

Our study reveals that bulking events are common at Fuego volcano, as we identify collapses in both October 2015 and June 2018. However, the unusually large collapse that occurred in June 2018 (thickness up to $68 \mathrm{~m}$ ) explains the increase of the run-out distance to $12 \mathrm{~km}$, which is 2-3 times longer than the usual 4-6 km reported for PDCs emplaced during moderate eruptions between 1999 and 2017 (Ferres and Escobar Wolf, 2018). This is one of many reasons why the 2018 event had a much larger impact on the surrounding population (e.g. hundreds of fatalities) in comparison with previous eruptions.

The increase of run-out distance caused by the large collapse demonstrates that the accumulation of volcanic material close to the vent constitutes a significant hazard. Collapse events can increase the volume and/or the mobility of PDCs during moderate explosive eruptions, which as a consequence will increase the impact on populations leaving down-slope of the volcano. We show that continuous monitoring of upper slopes of active volcanoes using high-resolution DEMs is critically important and that remote sensing could provide an effective mechanism for doing this routinely at all erupting volcanoes.

The methodology described in this paper can be applied to the longterm monitoring of mass accumulation/erosion around active volcanoes, especially steep-sided stratovolcanoes. The tracking of mass accumulation and slope stability at the upper slopes of andesitic volcanoes would be important for improving long-term hazard assessment and the mitigation of volcanic crisis such as the 2018 Fuego eruption.

\subsection{Limitations of remote sensing}

The co-eruptive DEM difference records of the summation of all topographic changes that occurred between 29 October 2015 and $06 \mathrm{Au}-$ gust 2018. During this period, 32 eruptions occurred at Fuego (including the eruption on June 3rd 2018), and eight of them produced PDCs in the upper parts of the Barranca Las Lajas (Naismith et al., 2019). We assume 
that the additional volumes associated with the eruptions in 2015 and 2016 are small compared to the volume of material deposited during June 3rd 2018. For example, the PDC emplaced in Las Lajas on 2 March 2016 only reached $3 \mathrm{~km}$ from Fuego's summit. Pyroclastic flow volume estimates for Barranca Las Lajas between October 2015 and early 2018 are not available, but volume estimates in other barrancas are much smaller than our total volume (e.g. $3.9 \times 10^{6} \mathrm{~m}^{3}$ in Barranca Honda and $0.7 \times 10^{6} \mathrm{~m}^{3}$ in Barranca Cenizas for the February 2018 eruption) (Chun et al., 2018).

TanDEM-X DEM corresponds to a Digital Surface Model (DSM) that includes the vegetation as X-band radar is scattered from the top of the trees. Therefore, flow thickness can be accurately resolved in vegetated areas if a pre-eruptive Digital Terrain Model (DTM) (e.g. bare earth free from vegetation) is available. For example, Lundgren et al. (2019) demonstrated the great benefit of using an airborne LIDAR (Light Detection and Ranging) DEM to derive flow thickness in forests during the 2018 Kilauea eruption. Unfortunately, no pre-eruptive DTM is available at Fuego volcano, and given the high levels of volcanic activity, any such model would need to be updated frequently. However, the volume of deposition on vegetated areas can be considered negligible for the 2018 Fuego eruption as the vegetation was mainly impacted by the ash cloud surge facies, which is usually associated with thin deposits ( $<1 \mathrm{~m}$ ) (Yamamoto et al., 1993; Gueugneau et al., 2019).

Real-time response to volcanic eruptions using remote sensing imagery depends on the frequency of acquisitions as well as the time taken to obtain, process and analyse the raw data. For the TanDEM-X mission, the repeat interval is 11 days, which in theory means it would be possible to produce an updated DEM within about 2 weeks of an eruption, with an average delay of about a week. However, no TanDEM-X acquisition was planned on Fuego volcano at the time of the eruption on June 2018. Two months passed between our data request and the acquisition of the first post-eruptive image (August 2018), with a further 2 months before it was released (October 2018). This delay meant the information about PDCs volumes could not be used for real-time response. For the 2018 Fuego eruption, the frequency of acquisition of TanDEM-X was not adequate to derive any pre-collapse movement or slope instability weeks to months before the eruption. We hope that future InSAR missions would help to better constrain the spatio-temporal evolution of the volume of materials that accumulates or collapses at the summit of stratovolcanoes, as it is relevant to better understand the recurrence of flow bulking and how it influences the impact of an eruption.

The TanDEM-X mission provides an unprecedented global dataset of high-resolution DEMs, which have been used in many fields of Earth Science. Here we have shown the value of repeated acquisition of DEMs for measuring rapid topographic changes at volcanoes. We also point out few limitations of TanDEM-X such as the frequency of acquisitions, the delay to release new data and the sensitivity of topographic changes to vegetation cover. Future bi-static missions such as DLR's planned mission TanDEM-L (Moreira et al., 2015) or ESA's proposed Earth Explorer mission Harmony (López-Dekker et al., 2019) will build on this experience and offer new perspectives to produce routinely high-resolution topographic data on volcanoes. Bi-static L-band $(23.6 \mathrm{~cm}$ ) radar missions would produce a Digital Terrain Model (bare Earth without vegetation) and would thus be expected to obtain more accurate estimates for the thicknesses and volumes of volcanic flows in vegetated regions. For any of these missions, reducing the time taken to acquire and release new imagery will be of great benefit for disaster management.

\section{Conclusions}

The combination of remote sensing datasets (Sentinel-2, TanDEM$\mathrm{X}$ ) has contributed to the better characterisation of the June 2018 Fuego PDCs. Using TanDEM-X DEM differencing, we obtain a thickness map for the PDCs, which clearly shows material loss in the proximal section of Barranca Las Lajas due to collapse and material deposition in the distal channel, near the town of San Miguel Los Lotes. The total derived volume of $15.1 \pm 4.2 \times 10^{6} \mathrm{~m}^{3}$ is a minimum volume but on the same order of magnitude as the rapid estimates made after the eruption of 3rd June 2018. In addition, our products, the thickness map and the post-eruptive topography, can be used for many other applications such as 1) the improvement of numerical simulations for future hazard mitigation or 2) the identification of locations that are more likely to be the source of material for PDCs bulking and lahars each rainy season for decades to come.

\section{CRediT authorship contribution statement}

F. Albino: Conceptualization, Investigation, Methodology, Data curation, Writing - original draft. J. Biggs: Conceptualization, Project administration, Funding acquisition, Writing - original draft. R. EscobarWolf: Formal analysis, Writing - review \& editing. A. Naismith: Writing - review \& editing. M. Watson: Conceptualization, Resources, Writing review \& editing. J.C. Phillips: Writing - review \& editing. G.A. Chigna Marroquin: Validation.

\section{Declaration of competing interest}

The authors declare that they have no known competing financial interests or personal relationships that could have appeared to influence the work reported in this paper.

\section{Acknowledgements}

This research was supported by the NERC Centre for the Observation and Modelling of Earthquakes, Volcanoes and Tectonics (COMET, http:// comet.nerc.ac.uk), a partnership between UK Universities and the British Geological Survey. We thank the UK Foreign and Commonwealth Office and the British Embassy in Guatemala for their support for the project entitled 'Technical assistance in response to Fuego Eruption', which partially supported this work. We acknowledge the CEOS DRR Volcano Pilot programme and the German Aerospace Center (DLR) for providing the TanDEM-X data under the proposal NTI_BIST7067. JCP acknowledges support through a University of Bristol Research Fellowship. We thank our colleagues, S. Ebmeier and E. Dualeh, for fruitful discussions about the 2018 Fuego eruption. We also thank P. Lundgren and an anonymous reviewer for their useful comments, which improved the manuscript.

\section{Appendix A. Supplementary data}

Supplementary data to this article can be found online at https://doi. org/10.1016/j.jvolgeores.2020.107063.

\section{References}

Albino, F., Smets, B., d’Oreye, N., Kervyn, F., 2015. High-resolution TanDEM-X DEM: an accurate method to estimate lava flow volumes at Nyamulagira Volcano (DR Congo). J. Geophys. Res. Solid Earth 120, 4189-4207.

Aldeghi, A., Carn, S., Escobar-Wolf, R., Groppelli, G., 2019. Volcano monitoring from space using high-cadence planet CubeSat images applied to Fuego Volcano, Guatemala. Remote Sens. 11, 2151.

Arnold, D., Biggs, J., Wadge, G., Ebmeier, S., Odbert, H., Poland, M.P., 2016. Dome growth, collapse, and valley fill at Soufrière Hills Volcano, Montserrat, from 1995 to 2013: contributions from satellite radar measurements of topographic change. Geosphere $12,1300-1315$

Arnold, D., Biggs, J., Anderson, K., Vallejo Vargas, S., Wadge, G., Ebmeier, S., Naranjo, M., Mothes, P., 2017. Decaying lava extrusion rate at El Reventador Volcano, Ecuador, measured using high-resolution satellite radar. J. Geophys. Res. Solid Earth 122 9966-9988.

Balzter, H., Baade, J., Rogers, K., 2016. Validation of the TanDEM-X intermediate digital elevation model with airborne LiDAR and differential GNSS in Kruger National Park. IEEE Geosci. Remote Sens. Lett. 13, 277-281.

Bernard, J., Kelfoun, K., Le Pennec, J.L., Vargas, S.V., 2014. Pyroclastic flow erosion and bulking processes: comparing field-based vs. modeling results at Tungurahua volcano, Ecuador. Bull. Volcanol. 76, 858. 
Calder, E., Sparks, R., Gardeweg, M., 2000. Erosion, transport and segregation of pumice and lithic clasts in pyroclastic flows inferred from ignimbrite at Lascar Volcano, Chile. J. Volcanol. Geotherm. Res. 104, 201-235.

Capra, L., Manea, V., Manea, M., Norini, G., 2011. The importance of digital elevation model resolution on granular flow simulations: a test case for Colima volcano using TITAN2D computational routine. Nat. Hazards 59, 665-680.

Charbonnier, S.J., Germa, A., Connor, C.B., Gertisser, R., Preece, K., Komorowski, J.C., Lavigne, F., Dixon, T., Connor, L., 2013. Evaluation of the impact of the 2010 pyroclastic density currents at Merapi volcano from high-resolution satellite imagery, field investigations and numerical simulations. J. Volcanol. Geotherm. Res. 261, 295-315.

Chun, C., Perez, S., Barrios, E., Calderas, A., 2018. Informe Mensual de la Actividad del Volcan de Fuego, Febrero 2018. Technical Report. INSIVUMEH. URL. http://www. insivumeh.gob.gt/geofisica/vulcanologia/fuego/MENSUAL/febrero/VFMFEB2018.pdf.

Cordonnier, B., Lev, E., Garel, F., 2016. Benchmarking lava-flow models. Geol. Soc. Lond., Spec. Publ. 426, 425-445.

Crosetto, M., 2002. Calibration and validation of SAR interferometry for DEM generation. ISPRS J. Photogramm. Remote Sens. 57, 213-227.

Dávila, N., Capra, L., Ferrés, D., Gavilanes-Ruiz, J.C., Flores, P., 2019. Chronology of the 2014-2016 eruptive phase of Volcán de Colima and volume estimation of associated lava flows and pyroclastic flows based on optical multi-sensors. Remote Sens. 11, 1167.

Dirscherl, M., Rossi, C., 2018. Geomorphometric analysis of the 2014-2015 Bárdarbunga volcanic eruption, Iceland. Remote Sens. Environ. 204, 244-259.

Ebmeier, S., Biggs, J., Mather, T., Elliott, J., Wadge, G., Amelung, F., 2012. Measuring large topographic change with InSAR: lava thicknesses, extrusion rate and subsidence rate at Santiaguito volcano, Guatemala. Earth Planet. Sci. Lett. 335, 216-225.

Ferres, D., Escobar Wolf, R., 2018. Informe Tecnico: Volcan de Fuego. Technical Report. Cooperacion Espanola. URL. http://bibliotecadigital.aecid.es/ bibliodig/il8n/consulta/registro. cmd?id=8751.

Fritz, T., Rossi, C., Yague-Martinez, N., Rodriguez-Gonzalez, F., Lachaise, M., Breit, H., 2011. Interferometric processing of TanDEM-X data. 2011 IEEE International Geoscience and Remote Sensing Symposium. IEEE, pp. 2428-2431.

Ganci, G., Cappello, A., Bilotta, G., Herault, A., Zago, V., Del Negro, C., 2018. Mapping volcanic deposits of the 2011-2015 Etna eruptive events using satellite remote sensing. Front. Earth Sci. 6, 83

Glennie, C.L., Carter, W.E., Shrestha, R.L., Dietrich, W.E., 2013. Geodetic imaging with airborne LiDAR: the Earth's surface revealed. Rep. Prog. Phys. 76, 086801.

Global Volcanism Program, 2013. Volcanoes of the World, v. 4.8.2. Smithsonian Institution https://doi.org/10.5479/si.GVP.VOTW4-2013 URL:

Gueugneau, V., Kelfoun, K., Druitt, T., 2019. Investigation of surge-derived pyroclastic flow formation by numerical modelling of the 25 June 1997 dome collapse at Soufrière Hills Volcano, Montserrat. Bull. Volcanol. 81, 25.

Hanssen, R.F., 2001. Radar Interferometry: Data Interpretation and Error Analysis. vol. volume 2. Springer Science \& Business Media.

Hofton, M.A., Malavassi, E., Blair, J.B., 2006. Quantifying recent pyroclastic and lava flows at Arenal Volcano, Costa Rica, using medium-footprint lidar. Geophys. Res. Lett. 33.

Iverson, R.M., 2012. Elementary theory of bed-sediment entrainment by debris flows and avalanches. J. Geophys. Res. Earth Surf. 117.

Jessop, D., Kelfoun, K., Labazuy, P., Mangeney, A., Roche, O., Tillier, J.L., Trouillet, M., Thibault, G., 2012. LiDAR derived morphology of the 1993 Lascar pyroclastic flow deposits, and implication for flow dynamics and rheology. J. Volcanol. Geotherm. Res. 245, 81-97.

Joyce, K.E., Belliss, S.E., Samsonov, S.V., McNeill, S.J., Glassey, P.J., 2009. A review of the status of satellite remote sensing and image processing techniques for mapping natural hazards and disasters. Prog. Phys. Geogr. 33, 183-207.

Kataoka, K.S., Matsumoto, T., Saito, T., Kawashima, K., Nagahashi, Y., Iyobe, T., Sasaki, A. Suzuki, K., 2018. Lahar characteristics as a function of triggering mechanism at a seasonally snow-clad volcano: contrasting lahars following the 2014 phreatic eruption of Ontake Volcano, Japan. Earth, Planets and Space 70, 113.

Kelfoun, K., 2011. Suitability of simple rheological laws for the numerical simulation of dense pyroclastic flows and long-runout volcanic avalanches. J. Geophys. Res. Solid Earth 116

Kelfoun, K., Druitt, T., 2005. Numerical modeling of the emplacement of Socompa rock avalanche, Chile. J. Geophys. Res. Solid Earth 110.

Kervyn, M., Kervyn, F., Goossens, R., Rowland, S., Ernst, G., 2007. Mapping volcanic terrain using high-resolution and 3D satellite remote sensing. Geol. Soc. Lond., Spec. Publ. 283, 5-30.

Krieger, G., Moreira, A., Fiedler, H., Hajnsek, I., Werner, M., Younis, M., Zink, M., 2007. TanDEM-X: a satellite formation for high-resolution SAR interferometry. IEEE Trans. Geosci. Remote Sens. 45, 3317-3341.

Kubanek, J., Richardson, J.A., Charbonnier, S.J., Connor, L.J., 2015. Lava flow mapping and volume calculations for the 2012-2013 Tolbachik, Kamchatka, fissure eruption using bistatic TanDEM-X InSAR. Bull. Volcanol. 77, 106

López-Dekker, P., Rott, H., Prats-Iraola, P., Chapron, B., Scipal, K., De Witte, E., 2019. Harmony: An Earth Explorer 10 Mission Candidate to Observe Land, Ice, and Ocean Surface Dynamics. IGARSS 2019-2019 IEEE International Geoscience and Remote Sensing Symposium. IEEE, pp. 8381-8384.

Lu, Z., Fielding, E., Patrick, M.R., Trautwein, C.M., 2003. Estimating lava volume by precision combination of multiple baseline spaceborne and airborne interferometric synthetic aperture radar: the 1997 eruption of Okmok volcano, Alaska. IEEE Trans. Geosci. Remote Sens, 41, 1428-1436.

Lundgren, P.R., Bagnardi, M., Dietterich, H., 2019. Topographic changes during the 2018 Klauea eruption from single-pass airborne InSAR. Geophys. Res. Lett. 46, 9554-9562.

Martin, D.P., Rose Jr, W.I., 1981. Behavioral patterns of Fuego volcano, Guatemala. J. Volcanol. Geotherm. Res. 10, 67-81.

Millan, R., Dehecq, A., Trouvé, E., Gourmelen, N., Berthier, E., 2015. Elevation changes and $\mathrm{X}$-band ice and snow penetration inferred from TanDEM-X data of the Mont-Blanc area. 2015 8th International Workshop on the Analysis of Multitemporal Remote Sensing Images (Multi-Temp). IEEE, pp. 1-4.
Moreira, A., Krieger, G., Hajnsek, I., Hounam, D., Werner, M., Riegger, S., Settelmeyer, E., 2004. TanDEM-X: A TerraSAR-X add-on satellite for single-pass SAR interferometry. IGARSS 2004. 2004 IEEE International Geoscience and Remote Sensing Symposium. IEEE, pp. 1000-1003.

Moreira, A., Krieger, G., Hajnsek, I., Papathanassiou, K., Younis, M., Lopez-Dekker, P., Huber, S., Villano, M., Pardini, M., Eineder, M., et al., 2015. Tandem-L: a highly innovative bistatic SAR mission for global observation of dynamic processes on the Earth's surface. IEEE Geoscience and Remote Sensing Magazine 3, 8-23.

Naismith, A.K., Watson, I.M., Escobar-Wolf, R., Chigna, G., Thomas, H., Coppola, D., Chun, C., 2019. Eruption frequency patterns through time for the current (1999-2018) activity cycle at Volcán de Fuego derived from remote sensing data: evidence for an accelerating cycle of explosive paroxysms and potential implications of eruptive activity. J. Volcanol. Geotherm. Res. 371, 206-219.

Neelmeijer, J., Motagh, M., Bookhagen, B., 2017. High-resolution digital elevation models from single-pass TanDEM-X interferometry over mountainous regions: a case study of Inylchek Glacier, Central Asia. ISPRS J. Photogramm. Remote Sens. 130, 108-121.

Ogburn, S.E., Calder, E.S., 2017. The relative effectiveness of empirical and physical models for simulating the dense undercurrent of pyroclastic flows under different emplacement conditions. Front. Earth Sci. 5, 83.

Pallister, J., Wessels, R., Griswold, J., McCausland, W., Kartadinata, N., Gunawan, H., Budianto, A., Primulyana, S., 2019. Monitoring, forecasting collapse events, and mapping pyroclastic deposits at Sinabung volcano with satellite imagery. J. Volcanol. Geotherm. Res. 382, 149-163.

Pardini, F., Queißer, M., Naismith, A., Watson, I., Clarisse, L., Burton, M., 2019. Initial constraints on triggering mechanisms of the eruption of Fuego volcano (Guatemala) from 3 June 2018 using IASI satellite data. J. Volcanol. Geotherm. Res. 376, 54-61.

Pierson, T.C., Janda, R.J., Thouret, J.C., Borrero, C.A., 1990. Perturbation and melting of snow and ice by the 13 November 1985 eruption of Nevado del Ruiz, Colombia, and consequent mobilization, flow and deposition of lahars. J. Volcanol. Geotherm. Res. 41, 17-66.

Poland, M.P., 2014. Time-averaged discharge rate of subaerial lava at Klauea Volcano, Hawai'i, measured from TanDEM-X interferometry: Implications for magma supply and storage during 2011-2013. J. Geophys. Res. Solid Earth 119, 5464-5481.

Pyle, D.M., Mather, T.A., Biggs, J., 2013. Remote sensing of volcanoes and volcanic processes: integrating observation and modelling-introduction. Geol. Soc. Lond., Spec. Publ. 380, 1-13.

Richter, N., Favalli, M., de Zeeuw-van Dalfsen, E., Fornaciai, A., Fernandes, R.M.d.S., Pérez N.M., Levy, J., Victória, S.S., Walter, T.R., 2016. Lava flow hazard at Fogo Volcano, Cabo Verde, before and after the 2014-2015 eruption. Nat. Hazards Earth Syst. Sci. 16.

Rodriguez, E., Martin, J., 1992. Theory and design of interferometric synthetic aperture radars. IEE Proceedings F (Radar and Signal Processing). IET, pp. 147-159.

Rose, W.I., Anderson Jr., A.T., Woodruff, L.G., Bonis, S.B., 1978. The October 1974 basaltic tephra from Fuego volcano: description and history of the magma body. J. Volcanol. Geotherm. Res. 4, 3-53.

Rose, W.I., Self, S., Murrow, P., Bonadonna, C., Durant, A.J., Ernst, G., 2008. Nature and significance of small volume fall deposits at composite volcanoes: Insights from the October 14, 1974 Fuego eruption, Guatemala. Bull. Volcanol. 70, 1043-1067.

Rowland, S.K., Harris, A.J., Wooster, M.J., Amelung, F., Garbeil, H., Wilson, L., MouginisMark, P.J., 2003. Volumetric characteristics of lava flows from interferometric radar and multispectral satellite data: the 1995 Fernandina and 1998 Cerro Azul eruptions in the western Galapagos. Bull. Volcanol. 65, 311-330.

Sahraoui, O.H., Hassaine, B., Serief, C., Hasni, K., 2006. Radar Interferometry with SarscapeSoftware. Shaping the Change XXIII FIG Congress Munich, Germany, October 8-13, 2006. PS 5.8 - Photogrammetry and Remote Sensing.

Schwarzkopf, L.M., Schmincke, H.U., Cronin, S.J., 2005. A conceptual model for block-andash flow basal avalanche transport and deposition, based on deposit architecture of 1998 and 1994 Merapi flows. J. Volcanol. Geotherm. Res. 139, 117-134.

Seymour, M., Cumming, I., 1994. Maximum likelihood estimation for SAR interferometry. Proceedings of IGARSS'94-1994 IEEE International Geoscience and Remote Sensing Symposium. IEEE, pp. 2272-2275.

Smets, B., Wauthier, C., d'Oreye, N., 2010. A new map of the lava flow field of Nyamulagira (DR Congo) from satellite imagery. J. Afr. Earth Sci. 58, 778-786.

Telling, J., Lyda, A., Hartzell, P., Glennie, C., 2017. Review of Earth science research using terrestrial laser scanning. Earth Sci. Rev. 169, 35-68.

Toutin, T., Cheng, P., 2001. DEM generation with ASTER stereo data. Earth Observation Magazine 10, 10-13.

Toutin, T., Gray, L., 2000. State-of-the-art of elevation extraction from satellite SAR data. ISPRS J. Photogramm. Remote Sens. 55, 13-33.

Waite, G.P., Nadeau, P.A., Lyons, J.J., 2013. Variability in eruption style and associated very long period events at Fuego volcano, Guatemala. J. Geophys. Res. Solid Earth 118, 1526-1533.

Watson, I., Realmuto, V., Rose, W.I., Prata, A., Bluth, G.J., Gu, Y., Bader, C., Yu, T., 2004. Thermal infrared remote sensing of volcanic emissions using the moderate resolution imaging spectroradiometer. J. Volcanol. Geotherm. Res. 135, 75-89.

Wessel, B., Huber, M., Wohlfart, C., Marschalk, U., Kosmann, D., Roth, A., 2018. Accuracy assessment of the global TanDEM-X Digital Elevation Model with GPS data. ISPRS J. Photogramm. Remote Sens. 139, 171-182.

Wright, R., Flynn, L., Garbeil, H., Harris, A., Pilger, E., 2002. Automated volcanic eruption detection using MODIS. Remote Sens. Environ. 82, 135-155.

Yamamoto, T., Takarada, S., Suto, S., 1993. Pyroclastic flows from the 1991 eruption of Unzen volcano, Japan. Bull. Volcanol. 55, 166-175.

Yulianto, F., Sofan, P., 2016. The utilization of remotely sensed data to analyze the estimated volume of pyroclastic deposits and morphological changes caused by the 2010-2015 eruption of Sinabung Volcano, North Sumatra, Indonesia. Pure Appl. Geophys. 173, 2711-2725.

Zink, M., Fiedler, H., Hajnsek, I., Krieger, G., Moreira, A., Werner, M., 2006. The TanDEM-X mission concept. 2006 IEEE International Symposium on Geoscience and Remote Sensing. IEEE, pp. 1938-1941. 